\title{
The Effects of two Organic Wastes Amendments on Uptake Levels of Heavy Metals by Maize Plant (Zea Mays L.) from Contaminated soil.
}

\author{
Chokor, Augustine A. \\ Department of chemistry, Federal University, Otuoke, Nigeria
}

\begin{abstract}
Contamination of soils with heavy metals is of environmental concern because accumulated metals may results in loss of ecosystem and agricultural productivity, diminished food chain quality, tainted water resources, economic loss, human and animal illness. Fixation treatment based on reduction of metals mobility and bioavailability could weaken the detrimental impacts on the environment. This study examine the utility of two natural wastes materials - rubber sludge (RS) and palm oil mill effluent (POME) - towards immobilization of heavy metals ( $\mathrm{Zn}, \mathrm{Mn}, \mathrm{Pb}, \mathrm{Cu}, \mathrm{Cr}, \& \mathrm{Cd})$ in soil using plant uptake as indicator. Contaminated soils from automobile workshops in Sapele were amended with different loads of natural wastes and amended soils were incubated for 20 days at ambient temperature before maize (Zea mays L.) were planted and allowed to grow for 21 days. The maize were then uprooted and analyzed for metal content. The result shows that amendments decrease heavy metals uptake by plant; indicating a decrease in mobile and bioavailable fractions of heavy metals in the soils compared to the un-amended control. The immobilization effectiveness was more for POME than $R S$.
\end{abstract}

Keywords:bioavailability, contaminated soil, heavy metals, in situ immobilization, organic wastes amendments, uptake level,

\section{Introduction}

Remediation of heavy metal contaminated soils requires their removal or immobilization and toxicity reduction. In situ immobilization (fixation) relies on the addition of an amendment to a contaminated soil in order to transform the fraction of toxic metals that is potentially mobile or bioavailable into forms that are less biologically available. Mobility is the capacity for toxic metals to move from contaminated site to any part of the soil or groundwater. Bioavailability connotes the fraction of a contaminant that can be taken into any biological entity such as plant, earthworm, or human. Various types of amendments such as fly ash, blast furnace slag, steel slag, red mud, bark/sawdust, composted wastes animal manure, industrial sludge and effluents have been used to immobilized metals in soils [1], [2], [3]. This work seeks to examine the effects of two natural wastes amendments - rubber sludge and palm oil mill effluent - in immobilizing heavy metals in soil using plant uptake as indicator.

\section{Materials and Methods}

Soil for the study was obtained from aggregate of top- soil $(0-15 \mathrm{~cm})$ samples of automobile workshops in Sapele. The two organic amendments used for this study were rubber sludge (RS) and palm oil mill effluent (POME). The rubber sludge was obtained from a rubber factory while the POME was from a local palm oil mill plant at Ajemele, both in Sapele. The physico-chemical properties of the soil and the organic wastes amendments were determined by standard methods [4], [5]. Amendments were thoroughly mixed with soil samples $(1 \mathrm{Kg})$ placed in an incubating container at different loading rate $-0,2,5,10,15$, and $20 \% \mathrm{w} / \mathrm{w}$. Deionized water was added to each soil mixture to bring it to $60 \%$ of it water holding capacity. Amended samples were allow to stand (at ambient temperature, $26-32^{\circ} \mathrm{C}$ ) with regular mixing and water losses throughout the incubation period were compensated by adding fresh distilled water. After 20 days of incubation at ambient temperature, maize (Zea mays L.) was planted and allowed to grow for 21days after germination. Maize plants on amended and un-amended soils were then uprooted washed thoroughly with running tap water. The whole plant tissues (roots, stems, and leaves) were cut into small pieces, dried for 2 days at $80^{\circ} \mathrm{C}$ and ashed in a Muffle furnace at $500^{\circ} \mathrm{C}$ for $6 \mathrm{hrs}$. The ash was dissolved in $20 \%$ nitric acid. The metal content was determined with Atomic Absorption spectrometer, Bulk Scientific VGP 210. The analyses were carried out in triplicates and the results are expressed as mean \pm standard deviation from the mean.

\section{Results}

The obtained results for selected physic-chemical properties and total levels of metals in the soil sample are summarized in Table 1, while that of the organic waste amendments are given in Table 2. High mean exchangeable cations were obtained for both RS and POME with pH medium of 4.90 and 5.90 respectively. 
Insignificant levels of some metals ( $\mathrm{Zn}, \mathrm{Mn}, \mathrm{Pb}, \mathrm{Cu}, \& \mathrm{Cr}$ ) however, were detected in both effluents. Cadmium was not detected in any of the effluents.

Table 1: Physico-chemical properties of the aggregated heavy metals contaminated soil from automobile workshops in Sapele.

\begin{tabular}{|l|l|}
\hline PARAMETERS & RESULTS \pm SD \\
\hline $\mathrm{pH}$ & $5.74 \pm 0.01$ \\
\hline Clay $(\%)$ & $7.80 \pm 0.55$ \\
\hline Silt $(\%)$ & $9.45 \pm 0.62$ \\
\hline Sand $(\%)$ & $82.75 \pm 0.25$ \\
\hline $\mathrm{TOC}(\%)$ & $1.08 \pm 0.30$ \\
\hline $\mathrm{OM}(\%)$ & $1.85 \pm 0.30$ \\
\hline $\mathrm{P}(\mathrm{mg} / \mathrm{Kg})$ & $32.01 \pm 7.20$ \\
\hline $\mathrm{CEC}(\mathrm{cmol} / \mathrm{Kg})$ & $11.21 \pm 0.45$ \\
\hline $\mathrm{Zn}(\mathrm{mg} / \mathrm{Kg})$ & $745.30 \pm 12.89$ \\
\hline $\mathrm{Mn}(\mathrm{mg} / \mathrm{Kg})$ & $181.61 \pm 6.54$ \\
\hline $\mathrm{Pb}(\mathrm{mg} / \mathrm{Kg})$ & $42.40 \pm 3.11$ \\
\hline $\mathrm{Cu}(\mathrm{mg} / \mathrm{Kg})$ & $103.73 \pm 5.17$ \\
\hline $\mathrm{Cr}(\mathrm{mg} / \mathrm{Kg})$ & $61.80 \pm 5.13$ \\
\hline $\mathrm{Cd}(\mathrm{mg} / \mathrm{Kg})$ & $9.05 \pm 1.09$ \\
\hline
\end{tabular}

Table 2: Physico-chemical properties of Rubber sludge (RS) and palm oil mill effluents (POME)

\begin{tabular}{|l|l|l|}
\hline \multirow{2}{*}{ PARAMETERS } & RESULTS \pm SD \\
\cline { 2 - 3 } & RS & POME \\
\hline $\mathrm{pH}$ & $4.90 \pm 0.00$ & $5.90 \pm 0.00$ \\
\hline $\mathrm{N}(\%)$ & $2.00 \pm 0.40$ & $0.29 \pm 0.00$ \\
\hline $\mathrm{P}(\mathrm{mg} / \mathrm{kg})$ & $53.02 \pm 3.80$ & $298.63 \pm 5.40$ \\
\hline $\mathrm{K}(\%)$ & $11.70 \pm 0.30$ & $27.20 \pm 1.10$ \\
\hline $\mathrm{Mg}(\%)$ & $3.10 \pm 0.90$ & $3.54 \pm 0.30$ \\
\hline $\mathrm{Ca}(\%)$ & $8.90 \pm 0.40$ & $9.60 \pm 0.40$ \\
\hline $\mathrm{TOC}(\%)$ & $2.20 \pm 0.00$ & $2.87 \pm 0.40$ \\
\hline $\mathrm{Zn}(\mathrm{mg} / \mathrm{kg})$ & $1.00 \pm 0.10$ & $3.20 \pm 0.00$ \\
\hline $\mathrm{Mn}(\mathrm{mg} / \mathrm{kg})$ & $0.10 \pm 0.00$ & $0.60 \pm 0.10$ \\
\hline $\mathrm{Pb}(\mathrm{mg} / \mathrm{kg})$ & $<0.08$ & $0.20 \pm 0.00$ \\
\hline $\mathrm{Cu}(\mathrm{mg} / \mathrm{kg})$ & $1.20 \pm 0.30$ & $2.70 \pm 0.30$ \\
\hline $\mathrm{Cr}(\mathrm{mg} / \mathrm{kg})$ & $0.10 \pm 0.00$ & $0.10 \pm 0.02$ \\
\hline $\mathrm{Cd}(\mathrm{mg} / \mathrm{kg})$ & $<0.01$ & $<0.01$ \\
\hline & & \\
\hline
\end{tabular}

The effects of the organic wastes (RS and POME) amendments on uptake levels of $\mathrm{Zn}, \mathrm{Mn}, \mathrm{Cu}, \mathrm{Cr}, \mathrm{Pb}$, and $\mathrm{Cd}$ from the contaminated soil samples by maize (Zea mays L.) are as shown in Table 3. The result shows that uptake of heavy metals by maize decreases with increase in amendments for both RS and POME. At 20\% amendment, reduction of $40 \% \mathrm{Zn}, 81 \% \mathrm{Mn}, 78 \% \mathrm{~Pb}, 43 \% \mathrm{Cu}, 91 \% \mathrm{Cr}$, and $90 \% \mathrm{Cd}$ were observed for RS amended soil. Similar decrease in level of metal uptake of $53 \% \mathrm{Zn}, 88 \% \mathrm{Mn}, 96 \% \mathrm{~Pb}, 46 \% \mathrm{Cu}, 97 \% \mathrm{Cr}$, and 95\% Cd were recorded for POME amended soil.

Table 3: Amount of metals in Maize harvested from rubber sludge (RS) and palm oil mill effluent (POME) amended soil.

\begin{tabular}{|c|c|c|c|c|c|c|}
\hline $\begin{array}{l}\text { Level of } \\
\text { amendment }\end{array}$ & $\mathrm{Zn}(\mathrm{mg} / \mathrm{kg})$ & $\mathrm{Mn}(\mathrm{mg} / \mathrm{kg})$ & $\mathrm{Pb}(\mathrm{mg} / \mathrm{kg})$ & $\mathrm{Cu}(\mathrm{mg} / \mathrm{kg})$ & $\mathrm{Cr}(\mathrm{mg} / \mathrm{kg})$ & $\mathrm{Cd}(\mathrm{mg} / \mathrm{kg})$ \\
\hline $\begin{array}{ll}0 \% & \mathrm{RS} \\
& \text { POME }\end{array}$ & $\begin{array}{l}23.80 \pm 2.00 \\
23.80 \pm 2.00\end{array}$ & $\begin{array}{l}8.60 \pm 1.30 \\
8.60 \pm 1.30\end{array}$ & $\begin{array}{l}4.05 \pm 1.10 \\
4.05 \pm 1.10\end{array}$ & $\begin{array}{l}33.90 \pm 2.90 \\
33.90 \pm 2.90\end{array}$ & $\begin{array}{l}4.50 \pm 1.30 \\
4.50 \pm 1.30\end{array}$ & $\begin{array}{l}2.38 \pm 0.40 \\
2.38 \pm 0.40\end{array}$ \\
\hline $\begin{array}{ll}2 \% & \mathrm{RS} \\
& \mathrm{POME}\end{array}$ & $\begin{array}{l}22.50 \pm 1.90 \\
21.50 \pm 1.30\end{array}$ & $\begin{array}{l}7.70 \pm 1.00 \\
7.30 \pm 1.00\end{array}$ & $\begin{array}{l}3.15 \pm 0.90 \\
3.00 \pm 0.90\end{array}$ & $\begin{array}{l}32.10 \pm 1.70 \\
30.90 \pm 1.40\end{array}$ & $\begin{array}{l}4.20 \pm 0.20 \\
3.60 \pm 0.90\end{array}$ & $\begin{array}{l}2.13 \pm 0.20 \\
2.50 \pm 0.20\end{array}$ \\
\hline $\begin{array}{ll}5 \% & \mathrm{RS} \\
& \text { POME }\end{array}$ & $\begin{array}{l}20.90 \pm 1.60 \\
19.30 \pm 1.40\end{array}$ & $\begin{array}{l}6.10 \pm 1.20 \\
5.50 \pm 1.40\end{array}$ & $\begin{array}{l}2.85 \pm 0.40 \\
2.10 \pm 0.40\end{array}$ & $\begin{array}{l}27.60 \pm 1.90 \\
27.30 \pm 130\end{array}$ & $\begin{array}{l}3.80 \pm 0.00 \\
2.40 \pm 0.60\end{array}$ & $\begin{array}{l}1.63 \pm 0.20 \\
1.38 \pm 0.20\end{array}$ \\
\hline $\begin{aligned} 10 \% & \text { RS } \\
& \text { POME }\end{aligned}$ & $\begin{array}{l}18.60 \pm 1.00 \\
16.80 \pm 1.10\end{array}$ & $\begin{array}{l}4.60 \pm 1.00 \\
4.20 \pm 1.10\end{array}$ & $\begin{array}{l}2.10 \pm 0.70 \\
1.35 \pm 0.10\end{array}$ & $\begin{array}{l}24.90 \pm 1.40 \\
25.20 \pm 1.10\end{array}$ & $\begin{array}{l}2.60 \pm 0.20 \\
1.80 \pm 0.10\end{array}$ & $\begin{array}{l}1.13 \pm 0.10 \\
0.87 \pm 0.15\end{array}$ \\
\hline $\begin{array}{rl}15 \% & \mathrm{RS} \\
& \text { POME }\end{array}$ & $\begin{array}{l}17.80 \pm 1.10 \\
13.40 \pm 1.20\end{array}$ & $\begin{array}{l}3.20 \pm 1.00 \\
2.80 \pm 0.00\end{array}$ & $\begin{array}{l}1.50 \pm 0.30 \\
0.60 \pm 0.10\end{array}$ & $\begin{array}{l}22.80 \pm 1.00 \\
21.90 \pm 1.00\end{array}$ & $\begin{array}{l}1.60 \pm 0.10 \\
0.60 \pm 0.00\end{array}$ & $\begin{array}{l}0.75 \pm 0.00 \\
0.38 \pm 0.05\end{array}$ \\
\hline $\begin{aligned} 20 \% & \text { RS } \\
& \text { POME }\end{aligned}$ & $\begin{array}{l}14.40 \pm 1.00 \\
11.20 \pm 1.00\end{array}$ & $\begin{array}{l}1.60 \pm 0.10 \\
1.00 \pm 0.00\end{array}$ & $\begin{array}{l}0.90 \pm 0.10 \\
0.15 \pm 0.03\end{array}$ & $\begin{array}{l}19.20 \pm 1.00 \\
18.30 \pm 1.20\end{array}$ & $\begin{array}{l}0.40 \pm 0.00 \\
0.14 \pm 0.01\end{array}$ & $\begin{array}{l}0.25 \pm 0.00 \\
0.10 \pm 0.01\end{array}$ \\
\hline
\end{tabular}

The uptake by maize of heavy metals in the soil showed strong negative correlation with amount of rubber sludge and palm oil mill effluents added to the soil (Table 4). 
Table 4: Coefficient of correlation between heavy metals' uptake by maize and amount and amount of amendments added to soil

\begin{tabular}{|l|l|l|l|l|l|l|}
\hline Amendment & \multicolumn{6}{|l|}{ Plant Uptake } \\
\hline & $\mathrm{Zn}$ & $\mathrm{Mn}$ & $\mathrm{Pb}$ & $\mathrm{Cu}$ & $\mathrm{Cr}$ & $\mathrm{Cd}$ \\
\hline RS & $0.9880^{* *}$ & $-0.9940 * *$ & $-0.9819 * *$ & $-0.9813 * *$ & $-0.9972 * *$ & $-0.9932 * *$ \\
& & & & & & \\
\hline POME & $0.9935^{* *}$ & $0.9878 * *$ & $-0.9641 * *$ & $-0.9858 * *$ & $-0.9737 * *$ & $-0.9594 * *$ \\
\hline
\end{tabular}

** significant at the \%1 level; *significant at the \%5 level

\section{Discussion}

The reductions in heavy metals' uptake by maize are associated with the capacity of the amendments to immobilized metals in the soil, which is, the transformation of the original soil metals to more geochemically stable phase via sorption, precipitation, and complexation process [6], [7]. If plant uptake levels sufficiently depict the effectiveness of metal immobilization, the results in Table 3 suggest that POME is relatively more effective in stabilization of heavy metals in soil than RS. The likely properties of the organic wastes that may show up as differences in immobilization efficiency are $\mathrm{pH}$, exchangeable cations, organic matter and phosphorous contents (Table 2). The values of exchangeable cations of POME were higher in magnitude than $\mathrm{RS}$ (K, Mg \& Ca values for POME were respectively 27.20, 3.54 and 9.60\% as compared to 11.70, 3.10 and $8.90 \%$ for RS). While the $\mathrm{pH}$ of POME (5.90) was closer and higher than that of soil (5.74) that of RS (4.90) show marked difference and should have perhaps affected metal availability in the amended soil. The $\mathrm{pH}$ of the soil system is a very important parameter, directly influencing sorption/desorption, precipitation/dissolution, complex formation, and oxidation-reduction reactions. The organic matter contents for both wastes were near (4.96\% POME \& $3.80 \%$ for RS) and should not have shown up as difference in immobilization efficiency. The large difference in phosphate contents $(298.63 \mathrm{mg} / \mathrm{kg}$ for POME \& $53.02 \mathrm{mg} / \mathrm{kg}$ for RS) perhaps is a factor contributing largely to the difference in immobilization efficiency of the two organic wastes. Phosphates addition to soil can enhance adsorption of metals ions or their precipitations as phosphates [8], [9].

\section{Conclusion}

Amendment of the heavy metals contaminated soil with two natural waste materials -rubber sludge and palm oil mill effluent - reduced the mobile and bio-available fractions of heavy metals in soils. This is reflected in the decrease in heavy metals uptake by maize plant compared with the un-amended control. The $\mathrm{pH}$, exchangeable cations, organic matter and phosphorous contents of the amendments are believed to be responsible for the immobilization effect. The relative immobilization efficiency of palm oil mill effluent over rubber sludge was ascribed mainly to higher $\mathrm{pH}$ and phosphate content.

\section{References}

[1]. G. Guo, Q. Zhou, and L.Q. Ma, Availability and assessment of fixing additives for in situ remediation of heavy metal contaminated soils: a review. Environmental monitoring and assessment, 116, 2006, 513-528.

[2]. J. Kumpiene, A. Lagerkvist, and C. Maurice, Stabilization of $\mathrm{As}, \mathrm{Cr}, \mathrm{Cu}, \mathrm{Pb}$, and $\mathrm{Zn}$ in soil using amendments-a review. Waste Management 28, 2008, 215-225.

[3]. M.J. Khan, M.T. Azeem, M.T. Jan, and S. Perveen, Effect of amendments on chemical immobilization of heavy metals in sugar mill contaminated soils, Soil Environ. 31(1), 2012, 55-66.

[4]. Y.P. Kaira and D.G. Maynard, Methods manual for forest soil and plant analysis. For. Can., Northwest Reg., North For. Cent.,(Edmonton, Alberta Canada, 1991) Inf. Rep. Nor. X-319, 17-108

[5]. ICARDA, Methods of soil, plant, and water analysis, International Centre for Agricultural Research in Dry Areas, (Beirut, Lebanon, 3013) 26-157.

[6]. Y. Hashimoto, H. Matsufuru, M. Takaoka, H. Tanida, and T. Sato, Impacts of chemical amendment and plant growth on lead speciation and enzyme activities in a shooting range soil: An X-ray absorption fine structure investigations. J. Environ. Qual., 38, 2009, 1420- 1428 .

[7]. Y. Zhou, and R. Haynes, Use of inorganic and organic waste for in situ immobilization of $\mathrm{Pb}$ and $\mathrm{Zn}$ in contaminated soil, Congress of Soil Sciences, Soil Solutions for changing world, Brisbane, Australia, 2010, 127-130

[8]. G.M. Heltiarachchi and G.M. Pierzynski, In situ stabilization of soil lead using phosphorus and manganese oxides: influence of plant growth, Environmental Sciences and Technology, 31, 2002, 564-572.

[9]. S. Raicevic, T. Kaludjerovic-Radoicic, and A.I. Zouboulis, In situ stabilization of toxic metals in polluted soils using phosphates: theoretical prediction and experimental verification. J. Hazard Mater, 117(1), 2005, 41-53. 